\title{
Board Independence, Nomination and Remuneration Committee, and Compensation in Indonesia
}

\author{
Puteri Alfarisa $^{1}$ and Iman Harymawan ${ }^{2}$ \\ ${ }^{1,2}$ Fakultas Ekonomi dan Bisnis Universitas Airlangga, Indonesia \\ Email Address: \\ puteri.alfarisa-2018@feb.unair.ac.id
}

\begin{abstract}
This article aims to examine the relationship between independent commissioners and nomination and remuneration committee (KNR) and their interaction with directors' compensation using companies listed on the Indonesia Stock Exchange (BEI) and ordinary least square regression analysis technique. This study found that independent commissioners negatively associated with directors' compensation which showed that companies with a higher ratio of independent commissioners provide less directors' compensation due to optimal supervision of management's opportunistic behavior. In contrast, KNR is positively associated with directors' compensation which means that companies with KNR provide greater compensation because, according to the "optimal contracting approach", the board is assumed to design compensation schemes to provide managers with efficient incentives to maximize shareholder value. Meanwhile, the interaction between the two variables is not associated with directors' compensation because of the negating effect which shows that companies with independent commissioners and KNR do not have a tendency for directors' compensation.
\end{abstract}

Keywords: Board Independence; Nomination and Remuneration Committee; Compensation.

Abstrak: Artikel ini bertujuan untuk menguji hubungan komisaris independen dan komite nominasi dan remunerasi (KNR) serta interaksinya dengan kompensasi direksi menggunakan perusahaan yang terdaftar di Bursa Efek Indonesia (BEI) dengan teknik analisis ordinary least square regression. Penelitian ini menemukan bahwa komisaris independen berhubungan negatif dengan kompensasi direksi yang menunjukkan bahwa perusahaan dengan rasio komisaris independen yang lebih tinggi memberikan kompensasi direksi yang lebih sedikit dikarenakan pengawasan optimal atas perilaku oportunistik manajemen. Sebaliknya, KNR berhubungan positif dengan kompensasi direksi yang berarti bahwa perusahaan dengan KNR memberikan kompensasi yang lebih besar karena, sesuai dengan "optimal contracting approach", dewan diasumsikan merancang skema kompensasi untuk memberikan manajer insentif untuk memaksimalkan nilai pemegang saham. Sementara itu, interaksi antara keduanya tidak berhubungan dengan kompensasi direksi karena efek saling meniadakan yang menunjukkan bahwa perusahaan dengan komisaris independen dan KNR tidak memiliki kecenderungan atas kompensasi direksi.

Kata Kunci: Komisaris Independen; Komite Nominasi dan Remunerasi; Kompensasi Direksi. 


\section{INTRODUCTION}

The topic of executive compensation has attracted much attention, both for shareholders, regulators, the media, and the general public (Bebchuk and Fried, 2003; Conyon, 2014; Conyon and Peck, 1998; Conyon et al., 2001; Elsayed and Elbardan, 2018; Frantz et al., 2013; Gill and Kohli, 2018; Manzaneque et al., 2015; Olaniyi and Obembe, 2017; Yarram and Rice, 2017). In this connection, Sur, (Magnan, and Cordeiro, 2015) state that although many studies have been carried out for decades, how to determine executive remuneration remains a puzzle. Furthermore, various studies were conducted to investigate the factors that influence executive compensation to learn corporate managerial theory and practice. Identification of several factors that affect executive remuneration has been carried out (Schmid and Wurster, 2016). For example, (Conyon et al., 2001) showed in agency problems that the company owner (principal) could not perfectly supervise the actions of the manager (agent) in carrying out company operations. Because agent behavior cannot be observed perfectly and monitoring their behavior is often expensive, agents or management can ignore shareholder welfare and maximize their profits (Huang et al., 2016). Then, (Kohli and Gill, 2019) explain that agents who are motivated by personal interests carry out opportunistic actions to achieve company goals based on this perspective. To anticipate this, to motivate management to choose actions that are in the owners' best interests, owners devise compensation contracts that make agent payments dependent on practical performance measures (Conyon et al., 2001; Li and Thibodeau, 2019).

Many researchers have focused on how executive compensation schemes can help alleviate agency problems in public companies. (Elsayed and Elbardan, 2018) describe a framework, and a pay-performance framework has been introduced to explain the relationship between executive compensation and company performance. The main focus of literature related to this framework has been derived from agency theory, which considers the positive relationship between agency-based contracts and firm performance. Design and executive remuneration levels are important incentives for management to act in owners' interests (Papenfu $\beta$ and Schmidt, 2016). In that case, the reward system is established to provide solutions to agency problems between principals and agents. However, it must be linked to organizational performance and company strategy and take into account the nature and growth of the company (Kirsten and Du Toit, 2018). Besides, (Rasoava, 2019) shows that the remuneration scheme is designed by a board that describes high compensation and organizational size, demand for management capabilities, and executive influence.

However, in practice, many companies are reluctant to disclose full details of how they link executive compensation and performance (Frantz et al., 2013). One possible reason for the lack of full disclosure is that managers exert their power (managerial power theory) to conceal the details of their compensation plans to disguise opportunistic rent extraction. In line with that, (Kwon et al., 2017) explained that, according to the CEO power approach, CEOs could use their power to influence board remuneration policies. CEOs have a significant effect in determining their remuneration and tend to be opportunistic in exploiting higher compensation payments that benefit them (Hoi et al., 2019). Meanwhile, in addition to the executive remuneration package's size and composition, shareholders also question the openness of the processes and criteria used in providing performance-based incentives (Mans-Kemp and Viviers, 2018). Based on this perspective, (Armstrong et al., 2012) investigated the relationship between corporate governance and the Chief Executive 
Officer's pay rate (CEO). The study results suggest that CEO salaries are higher in firms with weaker governance and that firms with weaker governance are more likely to use compensation consultants.

On the other hand, the study results also show that firms with weaker governance structures have greater agency problems and that CEOs in firms with larger agency problems receive considerable compensation and that firms with larger agency problems perform worse (Core et al., 1999). It reflects the need for a strong corporate governance mechanism to address agency problems related to compensation policies within the company. The problems in corporate governance can be related to top management remuneration overpayment (Jaafar et al., 2019).

In this regard, agency theorists view the main role of the board as a monitor of management behavior to protect the interests of owners (Cashen, 2014). Furthermore, (Ntim et al., 2015) explained that the board is a governance mechanism that plays an important role in making strategic decisions, including compensation policies. Empirical studies show that manager compensation is influenced by the effectiveness of board supervision, so that the monitoring role of independent directors is widely discussed in academic research (Benkraiem et al., 2017). Board independence is seen as a corporate governance mechanism that reduces opportunistic behavior and oversees board decisions, including compensation design.

On the other hand, agency theory also explains that an effective corporate governance mechanism is needed to reduce information asymmetry and related agency costs. For example, a board sub-committee works to monitor managers acting in the company's best interests. According to (Kanapathippillai et al., 2016), one of the important board subcommittees is the Nomination and Remuneration Committee (KNR), whose role is to support and advise the board on matters relating to remuneration. Therefore, the NRC regularly also attracts politicians' and regulators' attention because of their central role in setting CEO compensation and setting parameters for other senior executives' compensation (Sun et al., 2009).

Based on the description disclosed, the researchers are interested in analyzing the relationship between independent commissioners and the NRC and their interactions with directors' compensation in Indonesia. This research's motivation is because the independent commissioners and the National Audit Committee are part of the corporate governance system, which has a specific central role concerning the compensation policy for directors in the company. These two organs have an effective function in reducing opportunistic actions by management in terms of compensation to provide solutions to agency problems in the company. In connection with that, this study uses independent variables, including independent commissioners and NRC, and the dependent variable in directors' compensation. The sample used in this study is all companies on the Indonesia Stock Exchange (IDX) in 2010-2018.

The unique contribution expected from this study is the expansion of the literature on the relationship between independent commissioners and the NRR and its interaction with board compensation. As far as researchers have observed, there are no studies that have examined the relationship between these interactions. The interaction between the independent commissioners and the NRC will be tested whether it produces a governance mechanism that is more effective in managerial monitoring related to compensation for directors. Furthermore, this study was conducted using a sample from the IDX, in which the 
formation of the NRC is not mandatory (still voluntary), which can expand the literature by examining the generalization of the findings of previous NPC studies. Also, this study uses a more comprehensive measure of the existence and quality of NPC by using scores from the five committee characteristics to expand knowledge.

Furthermore, this article's structure includes explanations related to theory studies and hypothesis development in Part 2, a description of the research methodology used in Section 3, a discussion of empirical results in Section 4, and Section 5, which explains the conclusions of the findings of this study.

\section{THEORETICAL REVIEW}

(Ndzi, 2019) explains that executive compensation is part of the corporate culture, which is determined by the board with adjustments to company policies. On the other hand, any discussion about executive remuneration is always illustrated against the background of fundamental agency problems that affect management decision making (Benkraiem et al., 2017; Conyon, 1995;1997; Conyon and He, 2011; Conyon and Peck, 1998; Core et al., 2017; Conyon, 1995;1997; Conyon and He, 2011; Conyon and Peck, 1998; Core et al., 1999; Daily et al., 1998; Elsayed and Elbardan, 2018; Elston and Goldberg, 2003; Frantz et al., 2013; Kanapathippillai et al., 2019; Liang et al., 2015; Nannicini et al., 2018; Słomkagołębiowska, 2016). Bebchuk and Fried (2003) explain that the dominant approach to executive compensation studies views managers' payment arrangements as part of a deduction for agency problems among financial economists. Agency conflicts can be minimized effectively through director remuneration (Aslam et al., 2019; Rahmat et al., 2018). In line with this, (Mutlu et al., 2018) state that management incentives are an instrument to reduce moral hazard problems that arise from selfish managerial behavior. The absence of attractive incentives makes management unwilling to work to maximize shareholder value (Akram et al., 2019). Under this approach, compensation schemes are designed to provide managers with incentives to motivate them to improve performance to maximize shareholder value (Afrifa and Adesina, 2018; Buachoom, 2017; Kartadjumena and Rodgers, 2019).

(Majid et al., 2019) explained that, so far, business practice is based on agency theory. In line with that, agency theory has been used to explain and test organizational decisions and behavior for decades (Foreman and Howard, 2016). The classical agency theory's foundation shows a mismatch of interests between principal/owner and agent/management (Jong and Ho, 2018). This theory explains management's opportunistic behavior in carrying out company operations because of the information asymmetry between the principal and the agent (Ross, 1973; Jensen and Meckling, 1976). In this regard, with compensation, (Campbell et al., 2016) stated that agency theory has a main view on how incentives work within the company to align interests between owners and managers. Thus, agency theory provides the theoretical foundation of the monitoring function, which leads to the board's responsibilities to hire, fire, monitor, and pay salaries to executives on behalf of shareholders (Appiah and Chizema, 2015). On the other hand, (Janang et al., 2018) state that modern business requires a governance system to maintain company management balance. In this regard, in terms of remuneration, the purpose of the system is to ensure information regarding the determination of compensation that is considered fair (Ndzi, 2016). Therefore, to reduce agency problems, including in making decisions on compensation policies, a good 
corporate governance mechanism is needed, such as an independent commissioner in the company. (Habib and Bhuiyan, 2016) explain that the corporate governance mechanism's foundation lies on the company board. Also, (Marshall et al., 2019) stated that independent boards should defend shareholders' interests. Regulators have currently introduced an independent board system in Asia to improve corporate governance (Wei et al., 2018). Furthermore, several studies have explained a relationship between corporate governance, including board independence and executive compensation (Armstrong et al., 2012; Bebchuk and Fried, 2003; Conyon, 1997; Conyon and He, 2011); good diverse results. There is some evidence that governance variables play a role in shaping managing director salaries (Conyon, 1997).

Furthermore, (Conyon and $\mathrm{He}$, 2011) found that firms with more independent directors on the board have a higher pay-for-performance relationship. On the other hand, (Conyon and Peck, 1998) point to limited influence on board monitoring, a measure in terms of the proportion of non-executive directors. The existence of a remuneration committee and CEO duality towards top management compensation. Meanwhile, the study results support previous research findings that CEO salary levels are higher than expected by economic characteristics when corporate governance is weaker (Armstrong et al., 2012). (Bebchuk and Fried, 2003) concluded that executive power and rent extraction play an important role in executive compensation. The results show that companies with governance structures, including board independence, which are weaker have greater agency problems and that CEOs receive greater compensation in firms with greater agency problems and that firms with more agency problems. Large have poorer performance (Core et al., 1999).

In line with the explanation above, board independence is seen as a governance mechanism to reduce opportunistic actions and oversee board decisions and policies, including the compensation plan (Benkraiem et al., 2017). Therefore, this study examines the relationship between independent commissioners and director's compensation as the following hypothesis.

H1: Independent commissioners have a negative relationship with compensation for company directors.

Furthermore, (Fama and Jensen, 1983) explained that NPC's existence has relevance to agency theory which explains that management must be separate from control. The NRC, which has the responsibility of designing, managing, and monitoring executive compensation, plays a central role among some governance mechanisms that have the most influence on remuneration policies (Dell'Atti, 2013). In this regard, based on previous research, there are still inconsistencies in the results of studies regarding NPC's role in executive compensation. (Słomka-gołębiowska, 2016) shows that bank executives controlling shareholders and more independent board members on their remuneration committees are paid above average for the sample. (Kanapathippillai et al., 2019) also explained that the compensation committee is positively related to executive salary performance alignment. Meanwhile, (Conyon, 1997) explains that companies that adopt remuneration committees are seen, in some circumstances, as having lower growth rates in managing director compensation.

The existence and quality of the KNR within the company are seen as reinforcing the corporate governance mechanism. (Williamson, 1985) suggests that the absence of an 
independent remuneration committee would allow executives to write their contracts with one hand and sign them with the other. Based on the previous explanation, this study examines the relationship between NPC and the board of director's compensation as the following hypothesis.

H2: NPC has a negative relationship with the compensation of company directors.

Furthermore, this study aims to expand the previous literature by emphasizing the interaction relationship between independent commissioners and NPC with directors' compensation. The independent commissioner and the NRC are seen as strong corporate governance mechanisms in board decisions' effectiveness, including compensation design. Therefore, the hypothesis based on the above description is as follows.

H3: The interaction between independent commissioners and NPC is negatively related to the compensation of company directors.

\section{METHODS}

The quantitative research approach is the research approach used in this study. The dependent variable used is directors' compensation (COMP), measured using the natural logarithm of total compensation divided by the total number of directors (Elsayed and Elbardan, 2018). The independent variables used are independent commissioners (BI) and KNR (NRC). BI is measured using the board independence ratio (Benkraiem et al., 2017; Jong and Ho, 2019). The board independence ratio is the ratio of independent boards to board members as a whole. Meanwhile, NRC is measured using the presence of KNR (XC) through the dummy variable and the quality of the committee (QC) (Kanapathippillai et al., 2016; Kanapathippillai et al., 2019). Committee quality is the sum of five characteristics, including the number of members (dummy variable over median data), the proportion of independent members (dummy variable over median data), chairman independence (dummy variable), number of meetings (dummy variable over median data) and financial expertise of members (dummy variable).

Furthermore, the control variables used in this study include board size (BS), board age (AGE), cash liquidity (CL), company performance (FP), company size (FS), leverage (LE), sales growth (SG). The year and industry fixed effects (Benkraiem et al., 2017; Core et al., 1999; Dalton and Dalton, 2011; Elsayed and Elbardan, 2018; Nannicini et al., 2018; Ntim et al., 2015). The total number of boards measures BS, AGE which is the average age of the board. CL is the ratio of current assets to current liabilities. Also, FP is measured by the ratio of ROE (the ratio of net income to book value of total equity), FS is the natural logarithm of total assets, LE is measured by using the ratio of total debt to total assets, and $\mathrm{SG}$ is the difference between total sales minus the lag of total sales as measured by the lag of total sales. Meanwhile, year and industry fixed effects are control variables used in this study to accommodate differences in characteristics in observations (Gujarati and Porter, 2012).

The type of the study is panel data which is the combination of time series and crosssection data. 
The data source used in this study is secondary data obtained through the official IDX website. The data used in this study are financial reports and annual reports of all companies listed on the IDX in the 2010-2018 period. This study's data collection procedure was carried out using documentation through financial reports and annual reports of all companies listed on the Indonesia Stock Exchange (BEI) in the 2010-2018 period and also carried out by literature study to obtain information that can be used as a theoretical basis in this research.

The population in this study includes all companies listed on the IDX in the 20102018 period. The nine years were chosen to maintain the number of research samples, considering that the nomination and remuneration functions were voluntary for companies before the issuance of OJK Regulation Number 34 / POJK.04 / 2014 Nomination and Remuneration Committee of Issuers or Public Companies. The regulation also only stipulates the company's obligation to have a nomination and remuneration function. The board of commissioners must carry out these functions by establishing a KNR so that the KNR form is not yet mandatory. Besides, the selection of all industrial sectors is used to provide clearer results regarding the relationship between independent commissioners and the National Committee for Directors 'compensation to directors' compensation.

The sample selection was carried out through a purposive sampling method with an unbalanced panel data approach except for companies included in the financial, insurance, and real estate industries (companies with SIC code 6) and companies that did not have complete data and information related to the variables required in this study.

The analysis technique used in this research includes descriptive statistical analysis test, Pearson correlation test, independent t-test, and multiple linear regression analysis with STATA 14.0 software. The regression model used to test the hypothesis in this study is formulated as follows:

$$
\begin{aligned}
& \operatorname{COMP}_{i, t}=\beta_{0}+\beta_{1} B I_{i, t}+\beta_{2} N R C_{i, t}+\beta_{3} B I_{-} N R C_{i, t}+\beta_{4} B S_{i, t}+\beta_{5} A G E_{i, t}+\beta_{6} C L_{i, t}+ \\
& \beta_{7} F P_{i, t}+\beta_{8} F S_{i, t}+\beta_{9} L E_{i, t}+\beta_{10} S G_{i, t}+\beta_{11} Y E A R_{i, t}+\beta_{12} I N D U S T R Y_{i, t}+\varepsilon_{i, t}
\end{aligned}
$$

\section{RESULT AND DISCUSSION}

This study's objects are the independent commissioners, KNR, and compensation for directors, while the subjects in this study are all companies listed on the IDX for the 20102018 period. Based on the sample selection results, the total observations obtained in this study were 897 observations from 240 companies. Table 1 shows the results of descriptive statistics on the study variables for the 2010-2018 period. 
Table 1. Descriptive Statistics

\begin{tabular}{ccccc}
\hline Variabel & Mean & Median & Minimum & Maksimum \\
\hline COMP & 20.830 .000 .000 & 11.000 .000 .000 & 32.270 .397 & 186.800 .000 .000 \\
BI & 0,377 & 0,333 & 0,000 & 0,750 \\
XC & 0,380 & 0,000 & 0,000 & 1,000 \\
QC & 0,856 & 0,000 & 0,000 & 5,000 \\
BS & 9,493 & 9,000 & 4,000 & 20,000 \\
AGE & 54,039 & 54,000 & 42,333 & 67,000 \\
CL & 2,094 & 1,439 & 0,177 & 11,945 \\
FP & 5,473 & 7,190 & $-118,166$ & 122,990 \\
FS & 11.510 .000 .000 .00 & 3.470 .000 .000 .00 & 19.625 .532 .06 & 206.196 .000 .000 .00 \\
LE & 0 & 0 & 3 & 0 \\
SG & 0,491 & 0,502 & 0,080 & 0,943 \\
\hline
\end{tabular}

Source: Research Data 2020

Compensation/remuneration of directors (COMP) is the dependent variable that shows directors' total compensation. The average COMP value is 20,830,000,000. The lowest COMP value was 32,270,397, owned by Eratex Djaja Ltd Tbk in 2016, while the highest value was 186,800,000,000 owned by PT Mitra Adiperkasa Tbk in 2018.

Independent commissioner (BI) is an independent variable measured by the ratio of independent commissioners. BI has an average value of 0.377 . The lowest and highest values of this variable are 0 and 0.750 .

The existence of NPC (XC) is an independent variable measured using a dummy variable. The mean value of $\mathrm{XC}$ was 0.380 . The variable $\mathrm{XC}$ has a maximum and minimum value of 1 and 0 .

The NRC (QC) quality is an independent variable measured by the sum of the five quality characteristics of the committee. The QC variable has a mean of 0.856 . The minimum and maximum values of $\mathrm{QC}$ are 0 and 5.

Board size (BS) is a control variable that shows the number of commissioners and directors in a company. BS obtained an average of 9.493 and a median of 9 . The minimum and maximum values of the BS variable were 4 and 20 .

Board age (AGE) is a control variable that shows the company's average age. AGE has a mean value of 54.039. The minimum and maximum values are 42,333 and 67.

Cash liquidity (CL) is a control variable measured by current assets' ratio to current liabilities. CL obtained a mean value of 2.094 and a median of 1.439 . The minimum value is 0.177 , while the maximum value is 11.945 .

Firm performance (FP) is a control variable measured by net income ratio to the book value of total equity. The average value of FP was 5.473, and the median was 7.190. The minimum value is $-118,166$, while the maximum value is 122,990 .

Firm size (FS) is a control variable that shows the number of assets a company has. The average FS was $11,510,000,000,000$ and the median was $3,470,000,000,000$. The lowest FS value was 19,625,532,063, owned by Grahamas Citrawisata Tbk in 2011, while the highest value of 206,196,000,000,000 was owned by PT Telekomunikasi Indonesia (Persero) Tbk in 2018. 
The level of leverage (LE) is a control variable measured by the ratio between total debt and total assets. LE obtained a mean value of 0.491 and a median of 0.502 . The minimum value is 0.080 , and the maximum value is 0.943 .

Sales growth (SG) is a control variable which is the difference between total sales minus the lag of total sales as measured by the lag of total sales. The average value of the SG was 0.201 . The minimum and maximum values are -0.633 and 6.493 .

Furthermore, Table 2 displays the results of the Pearson correlation test. The results show a significant negative relationship at the $10 \%$ level between the BI and COMP. It shows that the greater the ratio of independent commissioners, the less compensation for directors. Then, the relationship between the XC and COMP variables was significantly negative at the $1 \%$ level. It shows that companies that have a $\mathrm{KNR}$ will provide less compensation for directors. Furthermore, the relationship between the QC and COMP variables was significantly negative at the $1 \%$ level. It shows that the higher the company's NRC's quality, the less compensation the directors have.

This test also indicates that there are some relationships between each control variable and the dependent variable. There is a significant negative relationship at the $1 \%$ level between BS, FP, FS, and LE with the COMP variable. It indicates that the board's size, company performance, size, and level of corporate leverage play a role in the relationship with company directors' compensation. On the other hand, there is a positive and significant relationship between the $1 \%$ and $5 \%$. Between CL, SG variables, and COMP variable. It shows that companies with high cash liquidity and sales growth will have higher compensation for directors. 
Table 2. Pearson Correlation Test Results

\begin{tabular}{|c|c|c|c|c|c|c|c|c|c|c|c|}
\hline & [1] & [2] & [3] & [4] & [5] & [6] & [7] & [8] & [9] & {$[10]$} & [11] \\
\hline $\begin{array}{l}{[1]} \\
\text { COM } \\
\text { P }\end{array}$ & 1,000 & & & & & & & & & & \\
\hline [2] BI & $\begin{array}{c}-0,065^{*} \\
(0,051)\end{array}$ & 1,000 & & & & & & & & & \\
\hline $\begin{array}{l}{[3]} \\
\mathrm{XC}\end{array}$ & $0,185^{* *}$ & 0,002 & 1,000 & & & & & & & & \\
\hline $\begin{array}{l}{[4]} \\
\text { QC }\end{array}$ & $\begin{array}{l}(0,000) \\
- \\
0,145^{* *}\end{array}$ & $\begin{array}{l}(0,955) \\
-0,006\end{array}$ & ${ }_{*}^{0,817^{* *}}$ & 1,000 & & & & & & & \\
\hline [5] BS & $\begin{array}{l}(0,000) \\
- \\
0,801^{* *}\end{array}$ & $\begin{array}{l}(0,858) \\
0,004\end{array}$ & $\begin{array}{l}(0,000) \\
0,317^{* *} \\
*\end{array}$ & $0,308^{* * *}$ & 1,000 & & & & & & \\
\hline $\begin{array}{l}{[6]} \\
\text { AGE }\end{array}$ & $\begin{array}{l}(0,000) \\
-0,047\end{array}$ & $\begin{array}{l}(0,911) \\
0,072^{* *}\end{array}$ & $\begin{array}{l}(0,000) \\
-0,002\end{array}$ & $\begin{array}{l}(0,000) \\
-0,015\end{array}$ & $0,122^{* *}$ & 1,000 & & & & & \\
\hline [7] CL & $\begin{array}{l}(0,163) \\
0,099^{* *} \\
*\end{array}$ & $\begin{array}{l}(0,032) \\
-0,046\end{array}$ & $\begin{array}{l}(0,952) \\
-0,003\end{array}$ & $\begin{array}{l}(0,644) \\
- \\
0,070^{* *}\end{array}$ & $\begin{array}{l}(0,000) \\
-0,053\end{array}$ & 0,030 & 1,000 & & & & \\
\hline [8] FP & $\begin{array}{l}(0,003) \\
- \\
0,110^{* *}\end{array}$ & $\begin{array}{l}(0,168) \\
- \\
0,150^{* *}\end{array}$ & $\begin{array}{l}(0,938) \\
0,078^{* *}\end{array}$ & $\begin{array}{l}(0,035) \\
0,023\end{array}$ & $\begin{array}{l}(0,110) \\
0,162^{* *} \\
*\end{array}$ & $\begin{array}{l}(0,364) \\
0,009\end{array}$ & $0,124^{* *}$ & 1,000 & & & \\
\hline [9] FS & $\begin{array}{l}(0,001) \\
- \\
0,455^{* *}\end{array}$ & $\begin{array}{l}(0,000) \\
0,059^{*}\end{array}$ & $\begin{array}{l}(0,020) \\
0,424^{* *} \\
*^{*}\end{array}$ & $\begin{array}{l}(0,493) \\
0,465^{* *} \\
*\end{array}$ & $\begin{array}{l}(0,000) \\
0,623^{* *} \\
*\end{array}$ & $\begin{array}{l}(0,777) \\
0,126^{* *} \\
*\end{array}$ & $\begin{array}{l}(0,000) \\
- \\
0,070^{* *}\end{array}$ & $0,146^{* *}$ & 1,000 & & \\
\hline $\begin{array}{l}{[10]} \\
\mathrm{LE}\end{array}$ & $\begin{array}{l}(0,000) \\
- \\
0,133^{* *}\end{array}$ & $\begin{array}{l}(0,077) \\
0,026\end{array}$ & $\begin{array}{l}(0,000) \\
0,035\end{array}$ & $\begin{array}{l}(0,000) \\
0,087^{* *}\end{array}$ & $\begin{array}{l}(0,000) \\
0,110^{* *}\end{array}$ & $\begin{array}{l}(0,000) \\
-0,007\end{array}$ & $\begin{array}{l}(0,037) \\
- \\
0,608^{* *}\end{array}$ & $\begin{array}{l}(0,000) \\
- \\
0,192^{* *}\end{array}$ & $0,186^{* *}$ & 1,000 & \\
\hline $\begin{array}{l}{[11]} \\
\text { SG }\end{array}$ & $\begin{array}{l}(0,000) \\
0,069^{* *}\end{array}$ & $\begin{array}{l}(0,436) \\
0,008\end{array}$ & $\begin{array}{l}(0,302) \\
- \\
0,070^{* *}\end{array}$ & $\begin{array}{l}(0,009) \\
-0,062^{*}\end{array}$ & $\begin{array}{l}(0,001) \\
- \\
0,078^{* *}\end{array}$ & $\begin{array}{l}(0,842) \\
- \\
0,124^{* *}\end{array}$ & $\begin{array}{l}(0,000) \\
0,008\end{array}$ & $\begin{array}{l}(0,000) \\
0,035\end{array}$ & $\begin{array}{l}(0,000) \\
-0,022\end{array}$ & $0,060^{*}$ & $\begin{array}{l}1,00 \\
0\end{array}$ \\
\hline & $(0,040)$ & $(0,807)$ & $(0,035)$ & $(0,063)$ & $(0,019)$ & $(0,000)$ & $(0,807)$ & $(0,292)$ & $(0,509)$ & $\begin{array}{l}(0,071 \\
{ }^{2}\end{array}$ & \\
\hline
\end{tabular}

Source: Research data, 2020. $\mathrm{p}$-values in parentheses $* \mathrm{p}<0.1, * * \mathrm{p}<0.05, * * * \mathrm{p}<0.01$

Table 3 shows the independent t-test on a group of companies with an NRC and companies that do not have an NPC. The results show that companies with an average KNR have lower compensation for directors than companies without an NPC. Then, the average ratio of independent commissioners is not significantly different for companies with KNR and companies that do not. Meanwhile, a company with a KNR had a higher quality KNR than a company without a KNR. 
Table 3. Independent T-Test based on the existence of the NRC

\begin{tabular}{lcccc}
\hline leVariabb & $\begin{array}{c}\text { Company with } \\
\text { KNR }\end{array}$ & $\begin{array}{c}\text { Companies } \\
\text { without a KNR }\end{array}$ & Coeficient & t-value \\
\hline COMP & 4,820 & 5,571 & $-0,750^{* * *}$ & $-5,637^{* * * *}$ \\
BI & 0,377 & 0,376 & 0,001 & 0,057 \\
QC & 2,252 & 0,000 & $2,252^{* * *}$ & $42,378^{* * *}$ \\
\hline
\end{tabular}

Source: Research data, 2020. $* * * t>2,326$

Table 4 shows the ordinary least square (OLS) regression results used to test the hypothesis in this study.

Table 4. Independent Commissioners and KNR with Compensation for Directors

\begin{tabular}{|c|c|c|c|c|c|c|c|}
\hline \multirow{2}{*}{ Variable } & \multicolumn{7}{|c|}{ COMP } \\
\hline & (1) & (2) & (3) & (4) & (5) & (6) & (7) \\
\hline \multirow[t]{2}{*}{ BI } & $-1,083^{* * *}$ & & & $-1,035^{\text {*** }}$ & $-0,985^{* * *}$ & $-1,241^{* * *}$ & $-0,999^{* * *}$ \\
\hline & $(-3,49)$ & & & $(-3,45)$ & $(-3,36)$ & $(-3,30)$ & $(-2,91)$ \\
\hline \multirow[t]{2}{*}{$\mathrm{XC}$} & & $0,408^{* * *}$ & & $0,397^{* * * *}$ & & 0,152 & \\
\hline & & $(4,87)$ & & $(4,73)$ & & $(0,62)$ & \\
\hline \multirow[t]{2}{*}{ QC } & & & $0,214^{* * *}$ & & $0,208^{* * *}$ & & $0,201^{* *}$ \\
\hline & & & $(7,01)$ & & $(6,90)$ & & $(2,54)$ \\
\hline \multirow[t]{2}{*}{ BI_XC } & & & & & & 0,641 & \\
\hline & & & & & & $(1,07)$ & \\
\hline \multirow{2}{*}{ BI_QC } & & & & & & & 0,018 \\
\hline & & & & & & & $(0,09)$ \\
\hline \multirow[t]{2}{*}{ BS } & $-5,124^{* * *}$ & $-5,190^{* * * *}$ & $-5,189^{* * *}$ & $-5,200^{* * *}$ & $-5,199^{* * *}$ & $-5,198^{* * *}$ & $-5,199^{* * *}$ \\
\hline & $(-31,74)$ & $(-31,78)$ & $(-32,23)$ & $(-32,45)$ & $(-32,82)$ & $(-32,42)$ & $(-32,69)$ \\
\hline \multirow[t]{2}{*}{ AGE } & $0,034^{* * * *}$ & $0,035^{* * *}$ & $0,037^{* * * *}$ & $0,038^{* * * *}$ & $0,040^{\text {**** }}$ & $0,038^{\text {**** }}$ & $0,040^{* * * *}$ \\
\hline & $(2,92)$ & $(2,98)$ & $(3,21)$ & $(3,23)$ & $(3,45)$ & $(3,23)$ & $(3,44)$ \\
\hline \multirow[t]{2}{*}{$\mathrm{CL}$} & 0,039 & 0,041 & $0,049^{*}$ & 0,037 & $0,045^{*}$ & 0,037 & $0,045^{*}$ \\
\hline & $(1,47)$ & $(1,58)$ & $(1,87)$ & $(1,42)$ & $(1,71)$ & $(1,40)$ & $(1,70)$ \\
\hline \multirow[t]{2}{*}{ FP } & $-0,001$ & $-0,001$ & $-0,000$ & $-0,002$ & $-0,001$ & $-0,001$ & $-0,001$ \\
\hline & $(-0,92)$ & $(-0,62)$ & $(-0,30)$ & $(-1,16)$ & $(-0,85)$ & $(-0,95)$ & $(-0,85)$ \\
\hline \multirow[t]{2}{*}{ FS } & $0,133^{* * *}$ & $0,089^{* * *}$ & 0,060 & $0,096^{* *}$ & 0,068 & $0,097^{* * *}$ & 0,068 \\
\hline & $(3,34)$ & $(2,15)$ & $(1,43)$ & $(2,33)$ & $(1,61)$ & $(2,34)$ & $(1,61)$ \\
\hline \multirow[t]{2}{*}{ LE } & $-0,352$ & $-0,299$ & $-0,293$ & $-0,345$ & $-0,338$ & $-0,339$ & $-0,338$ \\
\hline & $(-1,46)$ & $(-1,25)$ & $(-1,23)$ & $(-1,44)$ & $(-1,41)$ & $(-1,42)$ & $(-1,41)$ \\
\hline \multirow[t]{2}{*}{ SG } & 0,028 & 0,035 & 0,041 & 0,043 & 0,049 & 0,042 & 0,049 \\
\hline & $(0,59)$ & $(0,77)$ & $(0,91)$ & $(0,94)$ & $(1,07)$ & $(0,92)$ & $(1,07)$ \\
\hline \multirow[t]{2}{*}{ _cons } & $11,858^{* * *}$ & $12,192^{* * * *}$ & $12,801^{\text {*** }}$ & $12,426^{* * * *}$ & $13,008^{* * *}$ & $12,461^{* * *}$ & $13,011^{\text {*** }}$ \\
\hline & $(14,94)$ & $(14,76)$ & $(15,18)$ & $(15,38)$ & $(15,75)$ & $(15,37)$ & $(15,73)$ \\
\hline $\begin{array}{l}\text { Industry } \\
\text { dummy }\end{array}$ & Included & Included & Included & Included & Included & Included & Included \\
\hline $\begin{array}{l}\text { Year } \\
\text { dummy }\end{array}$ & Included & Included & Included & Included & Included & Included & Included \\
\hline$R^{2}$ & 0,675 & 0,677 & 0,684 & 0,681 & 0,688 & 0,682 & 0,688 \\
\hline$N$ & 897 & 897 & 897 & 897 & 897 & 897 & 897 \\
\hline
\end{tabular}


Specification (1) shows the OLS regression results that test the relationship between independent commissioners and several control variables used in this study with company directors' compensation. Furthermore, specification (2) shows the OLS regression results that test the relationship between NPC's presence and several control variables with compensation of company directors. Specification (3) shows the OLS regression results that test the relationship between the quality of the NRC and several control variables with company directors' compensation. Specification (4) shows the results of the OLS regression that jointly test the relationship between independent commissioners and the presence of NPC and several control variables with compensation of company directors. Specification (5) shows the OLS regression results that jointly test the relationship between independent commissioners and the NRC quality and several control variables with compensation of company directors. Specification (6) shows the OLS regression results that test the interaction relationship between independent commissioners and the presence of the NRC and several control variables with compensation of company directors. Finally, specification (7) shows the OLS regression results that test the interaction relationship between independent commissioners and the quality of the NRC and several control variables with the compensation of company directors.

The relationship between the BI and COMP variables is shown in Table 4. specifications (1). The BI variable's coefficient value is -1.083 with a t-value of -3.49 and is significant at the $1 \%$ level. This value indicates that with a 1 point increase in BI, the COMP will decrease by 1.083 . The regression results indicate that the independent commissioners have a significant negative relationship with the company directors' compensation. Thus, these results are consistent with the first research hypothesis (H1), which means that companies with a higher ratio of independent commissioners tend to produce lower compensation for directors. This study's results are consistent with the research of (Abdullah, 2006), who found that the level of board independence is associated with lower remuneration for directors. It has to do with a greater awareness of corporate governance. Overall, independent boards tend to be seen as effective monitors of board decisions (Benkraiem et al., 2017). Thus, a company with a high ratio of independent commissioners will produce less compensation for company directors. The regression results in the specification (1) also show that some of the control variables used have a relationship with company directors' compensation, which has various levels of significance. The results show that BS is significantly negatively associated with COMP at the $1 \%$ level. Then, the variables AGE and FS have a significant positive relationship with COMP at the $1 \%$ level.

The relationship between the XC and COMP variables can be seen in Table 4 . specifications (2). The $\mathrm{XC}$ variable's coefficient value is 0.408 with a t-value of 4.87 and is significant at the $1 \%$ level. It shows that with a 1 point increase in XC, the COMP will increase by 0.408 . From the regression results, it can be concluded that NPC's existence has a significant positive relationship with the compensation of company directors. This result is inconsistent with the second research hypothesis (H2), which states that NPC's presence is negatively related to the compensation of company directors, which means that companies that have NPC tend to produce lower compensation for directors.

On the other hand, the regression results explain that companies with a KNR tend to produce higher compensation for directors. Furthermore, the regression results in the specification (2) indicate that some control variables have a significant relationship with 
company directors' compensation. The results show that BS is significantly negatively associated with COMP at the $1 \%$ level. On the other hand, the variables AGE and FS had a significant positive relationship with COMP at the 1\% and 5\% levels. Meanwhile, the relationship between the QC and COMP variables is shown in Table 4. specifications (3). The QC variable coefficient value is 0.214 with a t-value of 7.01 and is significant at the $1 \%$ level. This value indicates that with a 1 point increase in QC, COMP will also increase by 0.214 . The regression results indicate that the NPC's quality has a significant positive relationship with the compensation of company directors. This result is inconsistent with the second research hypothesis (H2), which explains that higher NPC quality companies tend to produce lower compensation for directors.

On the other hand, the regression results explain that higher NPC quality companies tend to produce higher compensation for directors. The regression results in the specification (3) also show that several control variables have a significant relationship with company directors' compensation. The results show that BS is significantly negatively associated with COMP at the $1 \%$ level. The variables AGE and CL have a significant positive relationship with COMP at the $1 \%$ and $10 \%$ levels. Concerning these results, the possible reasons for not supporting the second hypothesis in this study are explained through an approach labeled "optimal contracting approach" (Bebchuk and Fried, 2003). Among financial economists, the dominant approach to executive compensation studies views managers' payment arrangements as part of the solution to agency problems. (Kent et al., 2018) explain that boards are assumed to design compensation schemes with executives to maximize shareholder value under this approach. The optimal contracting view recognizes that managers suffer from agency problems and do not automatically maximize shareholder value. Thus, providing adequate incentives to managers is important. Under the optimal contractual view, boards, working in shareholders' interests, seek to provide such incentives to managers through their compensation packages effectively. Likewise, in the corporate governance literature, and much more particularly in the executive compensation literature, there are alternative views on the efficiency of contractual arrangements observed between firms and executives (Guay et al., 2002). For the study and as an organizing principle for reviewing the related literature, we follow the framework of traditional agency-theory and define an efficient contract as one that maximizes the net economic value expected to shareholders after transaction costs (such as contract costs) and payment to employees. An equivalent explanation for this approach is the assumption that contracts minimize agency costs. (Ataay, 2018) and (Chen et al., 2017) explain that optimal contracts based on agency theory reference that companies use executive remuneration to minimize agency conflicts. Hence, companies with an NRC and the higher the NRC quality will tend to result in higher compensation for company directors.

Specifications (6) in Table 4 are the results of multiple linear regression between the compensation variable for company directors and the interaction variable, namely the independent commissioner and the NRC's existence. The relationship between BI_XC and COMP is positive and insignificant, with a coefficient of 0.641 and a t-value of 1.07. The regression results indicate that the interaction between independent commissioners and the NRC's presence is not related to the compensation of company directors. This result is inconsistent with the third research hypothesis $(\mathrm{H} 3)$, which explains that companies with independent commissioners and KNR tend to produce lower compensation for directors. On the other hand, the regression results explain that companies with independent 
commissioners and KNR do not compensate for directors. Finally, specification (7) in Table 4. shows the interaction relationship between $\mathrm{BI}$ and QC variables with COMP. The relationship between BI_QC and COMP is positive and insignificant, with a coefficient of 0.018 and a t-value of 0.09 . The regression results indicate that the interaction between independent commissioners and the NRC's quality is not related to the compensation of company directors. This result is also inconsistent with the third research hypothesis $(\mathrm{H} 3)$, which explains that companies with independent commissioners and higher quality of the NRC tend to produce lower compensation for directors. On the other hand, the regression results explain that companies with independent commissioners and the higher quality of the NRC do not tend to compensate the directors.

In connection with the results mentioned above, the regression analysis results on the first hypothesis show that companies with a higher ratio of independent commissioners will produce lower compensation for directors. It follows the view of board independence as an effective governance mechanism in reducing the occurrence of opportunistic behavior by management, including in compensation (Benkraiem et al., 2017). On the other hand, the regression analysis results on the second hypothesis show that companies with a higher NRR and quality of NPC will result in higher compensation for directors. This finding is inconsistent with the second hypothesis, which views the NRC as a reinforcement of corporate governance that prevents executives from determining their contracts (Williamson, 1985). Possible arguments for this inconsistency are explained based on the optimal contractual approach. This approach assumes that boards design compensation schemes to provide managers with efficient incentives to maximize shareholder value.

Meanwhile, the regression analysis results on the third hypothesis show that there is no interaction relationship between independent commissioners and NPC with compensation for directors. This result is inconsistent with the third hypothesis, which considers the independent commissioner and the NRC as a strong governance mechanism in terms of effective board decisions, including compensation. The possible reason for this result is the conflicting effects between the research results on the first and second hypotheses, resulting in a mutually exclusive relationship to the likelihood of the interaction results.

In connection with this, several studies have found no relationship between independent commissioners and the NRR and compensation for company directors (Anderson and Bizjak, 2003; Daily et al., 1998; Newman and Mozes, 1999). (Anderson and Bizjak, 2003) conducted a study to examine whether greater independence within the NRC increases shareholder interests and whether the CEO's presence in the NRC leads to an opportunistic payment structure. This study indicates that the NPC, which consists of insiders or CEOs, does not provide excessive wages or lower overall incentives. The researchers found no evidence that payments decreased or that real incentives increased when the CEO left the NPC. Furthermore, (Newman and Mozes, 1999) examined whether the composition of the KNR affects CEO compensation practices. This study's results do not find that CEO compensation is greater in companies that have insiders at NPC than in companies that do not have insiders at NPC.

Meanwhile, (Daily et al., 1998) examined the relationship between the company's NPC composition and various CEO compensation measures. The researchers found no evidence that directors led to a higher rate, or change, of CEO compensation. These findings, however, may not support the predictions of agency theory. One interpretation of the 
findings is that they suggest that directors serving on strong board committees, regardless of their degree of independence, are mindful of their shareholders' obligations.

\section{CONCLUSION}

The purpose of this study is to analyze the relationship of independent commissioners, the NRC, and the compensation of directors in all companies listed on the IDX period 20102018. Based on the results of the tests carried out, the following conclusions can be drawn. Independent commissioners have a significant negative relationship with compensation for company directors. It means that companies with a higher ratio of independent commissioners tend to produce lower compensation for directors. It is because independent commissioners tend to be able to exercise more effective supervision in monitoring managerial behavior. Independent commissioners have an incentive to monitor managerial actions effectively because they bear the burden of high reputation costs. Also, they are experts in the organization's internal control and have the relevant expertise to supervise the top management team to act according to company objectives which can minimize agency problems within the company.

NPC has a significant positive relationship with the compensation of company directors. It means that companies with a higher NRR and quality of KNR tend to produce higher compensation for directors. By the "optimal contracting approach" view, boards are assumed to design compensation schemes to provide managers with efficient incentives to maximize shareholder value. The optimal contracting view recognizes that managers suffer from agency problems and do not automatically maximize shareholder value. Thus, providing adequate incentives to managers is important. Under the optimal contractual view, boards, working in shareholders' interests, seek to provide such incentives to managers through their compensation packages effectively.

The interaction between the independent commissioners and the National Audit Committee is not related to company directors' compensation. The possibility of this result is due to the conflicting effects between the results of the study on the first and second hypotheses, resulting in mutually exclusive relationships with the tendency to the interaction results. This means that companies with independent commissioners and KNR do not have a tendency for directors' compensation.

This study has several limitations that can become recommendations for further research. First, in measuring compensation, this study only uses total compensation for the entire board of directors, so that it ignores the central position of the CEO, who has primary responsibility for the company's operations to shareholders. Second, the relationship between independent commissioners and NPC with compensation in this study was only tested through agency theory, so that it is not sufficient to understand the true relationship. Third, this study only uses independent commissioners and KNR as independent variables so that it is less comprehensive in examining the relationship of corporate governance as a whole.

In this connection, further research can use a proxy for the proportion of CEO compensation for the compensation for directors' variable to get more precise results on the study of the compensation. Then, future research can study the relationship between independent commissioners and NPC with compensation through other theories, such as stewardship theory, institutional theory, stakeholder theory, political theory, and ethical 
theories, which may be more suitable for the scope of this study. Furthermore, future studies can use other governance variables to investigate deeper relationships regarding this research.

\section{REFERENCES}

Abdullah, S. N. (2006). Directors ' remuneration, firm' s performance and corporate governance in Malaysia among distressed companies. Corporate Governance: The International Journal of Business in Society, 6(2), 162-174. https://doi.org/10.1108/14720700610655169.

Afrifa, G. A., and Adesina, O. O. (2018). How Does Directors Remuneration Affect SMEs' Performance? Review of Accounting and Finance, 17(2), 238-258.

Akram, F., Ul Haq, M. A., and Umrani, W. A. (2019). Assessing the Effect of Managerial Power on Firm Performance through the Perceptual Lens of Executive Remuneration. Pertanika Journal of Social Sciences and Humanities, 27(1), 293-309.

Anderson, R. C., and Bizjak, J. M. (2003). An empirical examination of the role of the CEO and the compensation committee in structuring executive pay. Journal of Banking \& Finance, 27(7), 1323-1348. https://doi.org/10.1016/S0378-4266(02)00259-5.

Appiah, K. O., and Chizema, A. (2015). Remuneration committee and corporate failure. Corporate Governance, 15(5), 623-640. https://doi.org/10.1108/CG-11-2014-0129.

Armstrong, C. S., Ittner, C. D., and Larcker, D. F. (2012). Corporate governance, compensation consultants, and CEO pay levels. Review of Accounting Studies, 17(2), 322-351. https://doi.org/10.1007/s11142-012-9182-y.

Aslam, E., Haron, R., and Tahir, M. N. (2019). How director remuneration impacts firm performance: An empirical analysis of executive director remuneration in Pakistan. Borsa Istanbul Review, 19(2), 186-196. https://doi.org/10.1016/j.bir.2019.01.003.

Ataay, A. (2018). Performance sensitivity of executive pay: the role of ownership structure, board leadership structure and board characteristics. Economic Research-Ekonomska Istraživanja, 31(1), 1152-1168. https://doi.org/10.1080/1331677X.2018.1456951.

Bebchuk, L. A., and Fried, J. M. (2003). Executive Compensation as an Agency Problem. Journal of Economic Perspectives, 17(3), 71-92.

Benkraiem, R., Hamrouni, A., Lakhal, F., and Toumi, N. (2017). Board independence, gender diversity and CEO compensation. Corporate Governance (Bingley), 17(5), 845-860. https://doi.org/10.1108/CG-02-2017-0027.

Buachoom, W. (2017). Simultaneous relationship between performance and executive compensation of Thai non-financial firms. Asian Review of Accounting, 25(3), 404423.

Campbell, C. J., Chang, R. P., DeJong Jr, J. C., Doktor, R., Oxelheim, L., and Randøy, T. (2016). The Impact of CEO Long-term Equity-based Compensation Incentives on Economic Growth in Collectivist versus Individualist Countries. Asian Economic Papers, 15(2), 109-133. https://doi.org/10.1162/ASEP_a_00432.

Cashen, L. H. (2014). Accountability at the Top: Executive Equity Ownership as an Alignment Mechanism in Times of Perceived Shareholder Neglect. Electronic Business Journal, 13(11), 794-810.

Chen, Z., Hung, W.-Y., Li, D., and Xing, L. (2017). The Impact of Bank Merger Growth on CEO Compensation. Journal of Business Finance and Accounting, 44(9-10), 1398- 
1442. https://doi.org/10.1111/jbfa.12263.

Conyon, M. J. (1995). Directors ' Pay in the Privatized Utilities. British Journal of Industrial Relations, 33(2), 159-171.

Conyon, M. J. (1997). Corporate governance and executive compensation. International Journal of Industrial Organization, 15(4), 493-509.

Conyon, M. J. (2014). Executive Compensation and Board Governance in US Firms*. The Economic Journal, 124(574), F60-F89. https://doi.org/10.1111/ecoj.12120.

Conyon, M. J., and He, L. (2011). Executive Compensation and Corporate Governance in China. Journal of Corporate Finance, 17(4), 1158-1175.

Conyon, M. J., and Peck, S. I. (1998). Board Control, Remuneration Committees, and Top Management Compensation. Academy of Management Journal, 41(2), 146-157.

Conyon, M. J., Peck, S. I., and Sadler, G. V. (2001). Corporate tournaments and executive compensation: Evidence from the UK. Strategic Management Journal, 22(8), 805815. https://doi.org/10.1002/smj.169.

Core, J. E., Holthausen, R. W., and Larcker, D. F. (1999). Corporate governance, chief executive officer compensation, and firm performance. Journal of Financial Economics, 51. https://doi.org/10.1016/S0304-405X(98)00058-0.

Daily, C. M., Dalton, R. D., Johnson, L. J., and Ellstrand, E. A. (1998). Compensation Committee Composition as a Determinant of CEO Compensation Author ( $\mathrm{s}$ ): Catherine M . Daily, Jonathan L. Johnson, Alan E . Ellstrand and Dan R . Dalton Source: The Academy of Management Journal, Vol .41, No . 2, Special Research Foru. Academy of Management Journal, 41(2), 209-220.

Dalton, D. R., and Dalton, C. M. (2011). Integration of micro and macro studies in governance research: CEO duality, board composition, and financial performance. Journal of Management, 37(2), 404-411. https://doi.org/10.1177/0149206310373399.

Dell'Atti, A., Intonti, M., and Iannuzzi, A. P. (2013). The effectiveness of remuneration committees in European banks: Regulation and best practices. Journal of Financial Regulation and Compliance, 21(4), 373-396. https://doi.org/10.1108/JFRC-11-20120046.

Elsayed, N., and Elbardan, H. (2018). Investigating the Associations between Executive Compensation and Firm Performance: Agency Theory or Tournament Theory. Journal of Applied Accounting Research, 19(2), 245-270.

Elston, J. A., and Goldberg, L. G. (2003). Executive compensation and agency costs in Germany. Journal of Banking \& Finance, 27(7), 1391-1410.

Fama, E. F., and Jensen, M. C. (1983). Separation of Ownership and Control. The Journal of Law \& Economics, 26(2), 301-325.

Foreman, P., and Howard, J. L. (2016). A Research Agenda for Examining the Role of Compensation Consultants in the Executive Pay Process. Employee Responsibilities and Rights Journal, 28(3), 191-208. https://doi.org/10.1007/s10672-016-9281-1.

Frantz, P., Instefjord, N., and Walker, M. (2013). Executive Compensation: A Model of Disclosure Choice. Journal of Business Finance \& Accounting, 40(9-10), 1184-1220. https://doi.org/10.1111/jbfa.12041.

Gill, S., and Kohli, M. (2018). Perceptual Determinants of Executive Compensation: Survey-Based Evidence from India. Indian Journal of Corporate Governance, 11(2), 1-26. https://doi.org/10.1177/0974686218797760. 
Guay, W. R., Core, J. E., and Larcker, D. F. (2002). Executive Equity Compensation and Incentives: A Survey. SSRN Electronic Journal, 27-50. https://doi.org/10.2139/ssrn.276425.

Habib, A., and Bhuiyan, M. B. U. (2016). Overlapping Membership on Audit and Compensation Committees and Financial Reporting Quality. Australian Accounting Review, 26(1), 76-90. https://doi.org/10.1111/auar.12086.

Hoi, C. K., Wu, Q., and Zhang, H. (2019). Does social capital mitigate agency problems? Evidence from Chief Executive Officer (CEO) compensation. Journal of Financial Economics, 133(2), 498-519. https://doi.org/10.1016/j.jfineco.2019.02.009.

Huang, S. S., Hirth, R. A., and Smith, D. G. (2016). Managers' Compensation in a Mixed Ownership Industry: Evidence from Nursing Homes. Frontiers in Public Health, 4, 283. https://doi.org/10.3389/FPUBH.2016.00283.

Jaafar, M. Y., Nawawi, A., and Salin, A. S. A. P. (2019). Factors Influencing Directors' Remuneration Disclosure in Malaysia PLCs. Pertanika Journal of Social Sciences \& Humanities, 27(2), 1049-1071.

Janang, J. T., Tinggi, M., and Kun, A. (2018). Technical inefficiency effects of corporate governance on government linked companies in Malaysia. International Journal of Business and Society, 19(3), 918-936.

Jensen, M. C., and Meckling, W. H. (1976). Theory of the Firm: Managerial. Journal of Financial Economics, 3(4), 305-360. https://doi.org/http://dx.doi.org/10.1016/0304405X(76)90026-X.

Jong, L., and Ho, P.-L. (2018). Inside the family firms: The impact of family and institutional ownership on executive remuneration. Cogent Economics \& Finance, 6(1), 1432095. https://doi.org/10.1080/23322039.2018.1432095.

Jong, L., and Ho, P.-L. (2019). Family directors, independent directors, remuneration committee and executive remuneration in Malaysian listed family firms. Asian Review of Accounting, 28(1), 24-47. https://doi.org/10.1108/ARA-04-2019-0099.

Kanapathippillai, S., Gul, F., Mihret, D., and Muttakin, M. B. (2019). Compensation committees, CEO pay and firm performance. Pacific Basin Finance Journal, 57(July), 101187. https://doi.org/10.1016/j.pacfin.2019.101187.

Kanapathippillai, S., Johl, S. K., and Wines, G. (2016). Remuneration committee effectiveness and narrative remuneration disclosure. Pacific-Basin Finance Journal, 40, 384-402.

Kartadjumena, E., and Rodgers, W. (2019). Executive Compensation, Sustainability, Climate, Environmental Concerns, and Company Financial Performance: Evidence from Indonesian Commercial Banks. Sustainability (Switzerland), 11(6), 1673. https://doi.org/10.3390/su11061673.

Kent, P., Kercher, K., and Routledge, J. (2018). Remuneration committees, shareholder dissent on CEO pay and the CEO pay-performance link. Accounting and Finance, 58(2), 445-475. https://doi.org/10.1111/acfi.12222.

Kirsten, E., and Du Toit, E. (2018). The relationship between remuneration and financial performance for companies listed on the Johannesburg Stock Exchange. South African Journal of Economic and Management Sciences, 21(1), 1-10.

Kohli, M., and Gill, S. (2019). Impact of family involvement on strategy and CEO compensation: Evidence from the Indian pharmaceutical industry. Journal of Family Business Management, 10(3), 189-212. https://doi.org/10.1108/JFBM-09-2019- 
0060.

Kwon, S., Yang, D., Song, J., and Jung, S. H. (2017). CEO Gender and Downward Pay Rigidities as Rent-extractions. Asian Women, 33(4), 1-26.

Li, Z., and Thibodeau, C. (2019). CSR-Contingent Executive Compensation Incentive and Earnings Management. Sustainability, 11(12), 3421.

Liang, H., Renneboog, L., and Sun, S. L. (2015). The political determinants of executive compensation: Evidence from an emerging economy. Emerging Markets Review, 25, 69-91. https://doi.org/10.1016/j.ememar.2015.04.008.

Majid, J., Mediaty, Habbe, A. H., Herryanto, and Possumah, B. T. (2019). Factors Affecting Director Remuneration: A Study of Manufacturing Companies Listed on ASEAN State Stock Exchanges. International Journal of Innovation, Creativity and Change, 7(9), 238-250.

Mans-Kemp, N., and Viviers, S. (2018). Executive performance evaluation and remuneration: Disclosure and practices of selected listed South African companies (2002-2015). South African Journal of Accounting Research, 32(2-3), 154-173. https://doi.org/10.1080/10291954.2018.1465149.

Manzaneque, M., Merino, E., and Ramírez, Y. (2015). Relationship between directors' compensation and business performance: One issue to debate. Corporate Board: Role, Duties \& Composition, 11(3), 166-175.

Marshall, A., Pinto, H., and Tang, L. (2019). Executive compensation in less regulated markets : the impact of debt monitoring. The European Journal of Finance, 25(18), 1883-1918. https://doi.org/10.1080/1351847X.2019.1668448.

Mutlu, C. C., Essen, M. Van, Peng, M. W., Saleh, S. F., and Duran, P. (2018). Corporate Governance in China: A Meta-Analysis. Journal of Management Studies, 55(6), 943 979. https://doi.org/10.1111/joms.12331.

Nannicini, A., Ferraz, D. P., and Lopes, I. T. (2018). Relationship between top executive compensation and corporate governance: evidence from large Italian listed companies. International Journal of Disclosure and Governance, 15(4), 197-209. https://doi.org/10.1057/s41310-018-0050-2.

Ndzi, E. (2016). Directors' pay regulation: "one goal two approaches." International Journal of Law and Management, 58(3), 337-352.

Ndzi, E. G. (2019). Executive remuneration: the power and dominance of human greed. Journal of Financial Crime, 26(4), 978-992. https://doi.org/10.1108/JFC-06-20170059

Newman, H. A., and Mozes, H. A. (1999). Does the composition of the compensation committee influence CEO compensation practices? Financial Management, 28(3), 41-53.

Ntim, C. G., Opong, K. K., and Danbolt, J. (2015). Board size, corporate regulations and firm valuation in an emerging market: a simultaneous equation approach. International Review of Applied Economics, 29(2), 194-220. https://doi.org/10.1080/02692171.2014.983048.

Olaniyi, C. O., and Obembe, O. B. (2017). Determinants of CEO pay: Empirical evidence from Nigerian quoted banks. International Journal of Business Performance Management, 18(3), 327-349.

Papenfuß, U., and Schmidt, C. (2016). Pay-Performance Relationship in German StateOwned Enterprises: Evidence and Reflection for Organizational Success Research 
with Undistorted and "Right" Data. Corporate Ownership \& Control, 13(2), 336-350. Rahmat, M. M., Amin, H. A. M., and Saleh, N. M. (2018). Controlling Shareholders' Networks and Related Party Transactions: Moderating Role of Director Remuneration in Malaysia. Jurnal Pengurusan, 53, 107-117. https://doi.org/10.17576/pengurusan2018-53-010.

Rasoava, R. (2019). Executive compensation and firm performance: a non-linear relationship. Problems and Perspectives in Management, 17(2), 1-17. https://doi.org/10.21511/ppm.17(2).2019.01.

Ross, S. A. (1973). The Economic Theory of Agency: The Principal's Problem Linked references are available on JSTOR for this article : The Economic Theory of Agency : The Principal' s Problem. The American Economic Review, 63(2), 134-139.

Schmid, S., and Wurster, D. J. (2016). Are international top executives paid more? Empirical evidence on fixed and variable compensation in management boards of German MNCs. European Journal of International Management, 10(1), 25-53. https://doi.org/10.1504/EJIM.2016.073981.

Słomka-gołębiowska, A. (2016). The Effect of Remuneration Committee Independence on the Pay-Performance Relationship: Evidence from the Banking Industry in Poland. Eastern European Economics, 54(1), 71-89. https://doi.org/10.1080/00128775.2015.1110489.

Sun, J., Cahan, S. F., and Emanuel, D. (2009). Compensation committee governance quality, chief executive officer stock option grants, and future firm performance. Journal of Banking and Finance, 33(8), 1507-1519. https://doi.org/10.1016/j.jbankfin.2009.02.015.

Sur, S., Magnan, M., and Cordeiro, J. (2015). Disentangling CEO compensation: A simultaneous examination of time, industry, and firm-level effects. Canadian Journal of Administrative Sciences, 32(1), 30-46. https://doi.org/10.1002/cjas.1304.

Wei, W., Tang, R. W., and Yang, J. Y. (2018). Independent directors in Asian firms: An integrative review and future directions. Asia Pacific Journal of Management, 35(3), 671-696.

Yarram, S. R., and Rice, J. (2017). Executive compensation among Australian mining and non-mining firms: Risk taking, long and short-term incentives. Economic Modelling, 64, 211-220. https://doi.org/10.1016/j.econmod.2017.03.034. 